\title{
The Significance and Impact of Innovation Networks of Academia and Business with a Special Emphasis on Work-Based Learning
}

\author{
Max A. Hogeforster \\ Baltic Sea Academy \\ Blankeneser Landstrasse 7, \\ Hamburg 22587, Germany \\ E-mail: mhogeforster@hanse-parlament.eu \\ Elina Priedulena \\ Hanse Parlament \\ Blankeneser Landstrasse 7, \\ Hamburg 22587, Germany \\ E-mail: epriedulena@hanse-parlament.eu
}

\begin{abstract}
The Europe 2020 Strategy puts the quality and relevance of education and training systems at the heart of EU's efforts to improve innovation and competitiveness and to achieve intelligent, sustainable and inclusive growth. The development of partnerships between vocational schools or higher-education institutions and the business sector must be considered as a critical factor in identifying learning requirements, improving the relevance of education and facilitating access to education and learning. The growing lack of skills is one of the major challenges for companies that rely on more highly qualified personnel. To increase the cooperation between academia and the business world means to integrate small and medium-sized enterprises (SMES), since 99.2 per cent of European businesses are SMEs. They are the blood cells of the European economy and are essential for growth, yet a very heterogeneous group that can only be integrated in cooperation networks by intermediate organisations which tackle the needs of this diverse group of businesses. Such a partnership of 17 universities and polytechnics, including the University of Latvia, was founded in 2010 and is shortly introduced as a best practice example.
\end{abstract}


To stay competitive in the globalised world, companies need to be innovative and that requires cooperation with knowledge institutions. A survey conducted in 2013 revealed that one of the major obstacles for SMEs to improve their innovation capabilities is their inability to find qualified personnel. This corresponds to the huge challenges the labour markets face in Europe. Almost all countries report a growing lack of skilled workforce while at the same time youth unemployment is increasing. This gap between the current qualifications and the qualifications demanded by businesses sector can be overcome by a closer cooperation between enterprises and education facilities, on a national but also international level between Western and Eastern countries. The introduction of work-based education plays a crucial role in narrowing this divide.

Keywords: innovation network, partnership, qualification, SMEs, work-based learning

\section{Introduction}

Following and extending the Lisbon Strategy from 2010, the European Union adopted the Europe 2020 Strategy in 2010, with the overall goal to strengthen the knowledge-based society, putting a strong emphasis on progress in the fields of research, education and innovation (Soriano \& Mulatero, 2010). The blood cells for a successful implementation of this strategy are the European SMEs that have a large share in the macro economy and employment in Europe. Companies with less than 250 employees and equal or less than either 50 million euros turnover or 43 million euros balance sheet total are considered small and medium-sized enterprises (Lukács, 2005). Micro-enterprises are the smallest category of SMEs, with less than ten employees and a turnover or balance sheet total equal to or less than 2 million euros (European Commission, 2011). Over 99 per cent of all European enterprises are SMEs, providing up to 70 per cent of all jobs. In fact, between 2002 and 2010 about 85 per cent of net new jobs were created by small and medium-sized enterprises (de Kok et al., 2011). Also, during the crisis in 2008, employment by SMEs proved to be more resilient than employment by large firms (Gagliardi et al., 2013). These numbers clearly show why small and medium-sized enterprises are often referred to as the backbone and the driving force of the social and economic development in Europe (Wymenga et al., 2011). 
A strong SME environment is vital to realise the ambitious goals of the Europe 2020 Strategy, but European SMEs need support to stay competitive in the globalised economy. The markets are getting fiercer and single companies hardly have a chance to run monopolies in their fields. Due to relatively high tax rates and social costs, in particular in the Baltic Sea Region, the local companies cannot compete with other countries in terms of prices, but only by offering products and services of high quality and reliability. This asks for an innovative environment and for outstanding qualifications, to secure competitive companies in the long run. An improved innovation infrastructure as well as better qualifications fitting the needs of SMEs ask for specific transnational partnerships.

\section{Baltic Sea Academy as an exemplary partnership}

Qualifications and innovations for SMEs must be realised with a cooperation of different institutions as well as international activity. Companies in particular benefit from these international relationships (Holm et al., 1996). Thus, organisations representing and working for SMEs, such as business chambers, need to be connected on an international level. Such a non-profit network of partners is the Hanse Parlament, bringing together more than 50 chambers from 12 countries - a non-profit network of countries in Western and Eastern Europe. Such networks offer the external resources that can be of vital importance for small businesses (Street \& Cameron, 2007).

This business network then formed a partnership with academic institutions. The increasing role universities play in the economy and the impact they exert on promotion innovation is unquestionable (Abreu et al., 2008). Yet, most of the cooperation between the business sector and academic world focused on major companies and industries, not on SMEs. To establish this missing link, the Hanse Parlament invited ten universities and polytechnics from seven countries to establish a partnership between the academic and business world for the benefit of SMEs in 2010. This partnership, called the Baltic Sea Academy, forms the first network of higher-education institutions (HEIs) for the support of small and medium-sized enterprises. By 2014, this network had grown to 17 members from 9 countries, such as Belarus, Denmark, Germany, Latvia, Lithuania, Poland, Sweden, and Russia. It is important to have such geographical coverage, so the partners can contribute to the network according to their regional strengths. This partnership realises tangible R\&D solutions for companies and creates curricula for vocational trainings and dual study courses, 
thus tackling the important topics of education (see subchapter 2.1 below) and innovation (see subchapter 2.2). These can be combined in a work based learning environment (see subchapter 2.3).

\subsection{Partnership offering education}

One of today's biggest obstacles for the SMEs that wish to expand is the pure lack of skilled workforce. A survey, conducted in 2013 among more than 600 stakeholders, such as SME associations, business chambers, and universities, revealed that the missing workforce is the major hindrance. The participants were asked to indicate on a scale of 1 to 5, in which area they consider SMEs need the most support to stay competitive, with 1 indicating not important and 5 most important. By far, the participants indicated with 4.6 that qualified staff is the most essential prerequisite, followed by 4.17 for good work climate in a company. Information, political and financial support were clearly rated as less significant (Fig. 1). Evidently, political or even financial support was rated clearly lower.

Figure 1. Areas that SMEs have the highest support need to become/stay innovative, data from own survey 2013

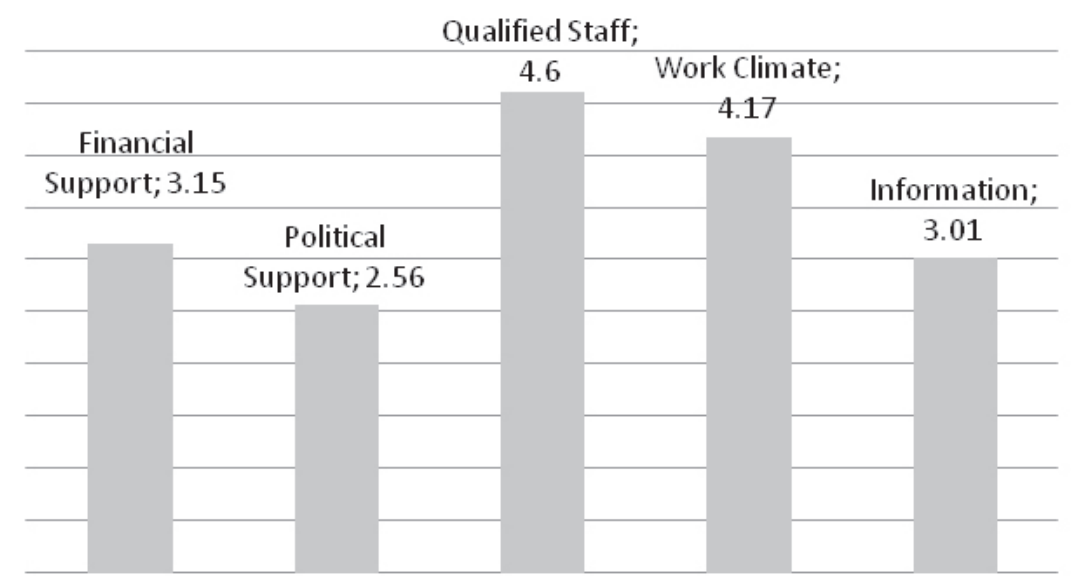

While unemployment was seen as one of the biggest challenges for the European economy in the late 1990s (Siebert, 1997), today the lack of skilled workforce is taking a prominent role and poses a serious threat for the economy. Even though many countries still have a high or even rising unemployment, in all European countries the number of job vacancies is rising dramatically and there is fierce competition for qualified workforce in Europe. For example, German companies advertise on the Polish labour market, German workforce migrates to Denmark; Danes might be attracted by the high wages in Norway. 
As a result, there is a great threat of a shortage of skilled workers especially for the SMEs, which may be pushed towards lower levels of qualification. However, SMEs require the best available talents to stay competitive. The European workforce skills are not matched with the labour market needs-Europe's most talented and needed workforce is being wasted (Cedefop, 2014). This skill mismatch is one of the most pressing topics for European economy.

This development of a growing lack of skills is getting even stronger due to the demographic changes. With the exception of Sweden, the population of working age will decrease by 5 to 17 per cent in all countries around the Baltic Sea by the year 2030 (Stiller \& Faltermeier, 2011).

Table 1 indicates that particularly in Eastern European Member States, such as Latvia or Lithuania, there is a strong decrease of more than 8 per cent of employable population. In particular, the Baltic States face not only the demographic change, but are also burdened by the so-called brain drain, where the highly qualified and best talents emigrate to other countries due to a lack of available jobs, resulting in a dangerous downward spiral. For example, Lithuania lost at least 17.2 per cent of its population between 1989 and 2011 (Ubarevičienè et al., 2014).

Table 1. Population, population change and employable population change in the Baltic Sea region, 2010-2020

\begin{tabular}{|l|c|c|c|c|}
\hline & Population & Population & $\begin{array}{c}\text { Population } \\
\text { change }\end{array}$ & $\begin{array}{c}\text { Employable } \\
\text { population } \\
\text { change }\end{array}$ \\
\hline & $\mathbf{2 0 1 0}$ & $\mathbf{2 0 2 0}$ & $\mathbf{2 0 1 0 - 2 0 2 0}$ & $\mathbf{2 0 1 0 - 2 0 2 0}$ \\
\hline EU27 & $\mathrm{mln}$ & $\mathrm{mln}$ & $\%$ & $\%$ \\
\hline Denmark & 501.1 & 514.4 & 2.6 & -1.5 \\
\hline Germany & 5.5 & 5.7 & 3.4 & -0.5 \\
\hline Estonia & 81.8 & 80.1 & -2.1 & -4.3 \\
\hline Finland & 1.3 & 1.3 & -1.2 & -7.2 \\
\hline Latvia & 5.4 & 5.6 & 4.2 & -4.1 \\
\hline Lithuania & 2.2 & 2.1 & -4.8 & -8.8 \\
\hline Norway & 3.3 & 3.2 & -4.5 & -8.3 \\
\hline Poland & 4.9 & 5.1 & 5.7 & 6.8 \\
\hline Russia & 38.2 & 38.4 & 0.6 & -6.2 \\
\hline Sweden & 143.0 & 141.0 & -1.4 & -7.7 \\
\hline
\end{tabular}

Sources: Eurostat, 2012; Russia: UN World Population Prospects, 2010; After Biermann et al., 2013. 
Undeniably, youth unemployment is rising in Europe (Eichhorst, 2013), but so is the number of job vacancies. Many trainee positions, in particular in the craft sector cannot be filled.

The offered qualifications must be more closely linked to the real market needs. Too many young people leave schools without employable qualifications. Universities do not only have the responsibility to create employable workers (Teichler, 2013), they also need to create critical, open minds. Still, in light of the rising number of young academics in most European countries without employment, it seems obligatory to match the existing curricula closer to the real needs of the businesses.

Since the majority of all jobs are created in SMEs, their needs must be considered when drafting new trainings and study courses. Since SMEs are a very heterogeneous group, their needs must be gathered by umbrella organisations, such as business chambers, in the respective regions. These chambers must cooperate on a transnational basis with educational institutions that create and offer the respective curricula.

\subsection{Partnership for innovation and open innovation}

Educational products are the best possible long-term investments to create a strong economy, but companies also need innovative solutions in a short period. Usually SMEs plan for three to six months ahead, not years ahead like major companies. Small firms need solutions within this time period. No matter how important future qualified workforce is, the companies also need support to identify and improve future products and services they can offer a high-quality market such as Europe.

To stay competitive against the fast-growing low labour cost countries like China, SMEs need to be more innovative (Heinonen, 2010). This has become even more the case in recent years, since those major economies are rapidly developing from pure production markets to innovative economies (Altenburg, 2008). Undeniably, the increased global competition, the impact of foreign competition has resulted in increased innovation activities also in traditional low labour cost countries like China (Liu et al., 2014).

For a growing economy, the breakthrough innovations, a new revolutionary technology or service, for example, are the most important. In the last decades, the majority of these were realised by small firms, while the big companies concentrated on incremental innovations to improve their existing products 
(Baumol, 2002). It must be noted that innovations in companies should not be understood as technological improvements only, but there is a rising need for non-technological or so-called soft innovations in companies (Hogeforster, 2014).

There is a need for partnerships with research facilities to allow companies to raise their level of innovations. The abovementioned 2013 survey asked as to which stakeholder SMEs need to have a close cooperation with to develop innovative solutions. In the survey, 1 marked a low level of cooperation, 5 a high level of cooperation. The respondents indicated that it is most important to cooperate with educational institutions (4.21), followed by business chambers (3.8) and R\&D institutes (3.37). Cooperation with private consultants (1.97), public administrations (2.41) and financial institutions (2.5) was regarded as less important. The survey revealed that a stronger need for open innovation is needed in EaP countries like Belarus.

Figure 2. Cooperation needs of SMEs to be innovative, data from own survey 2013

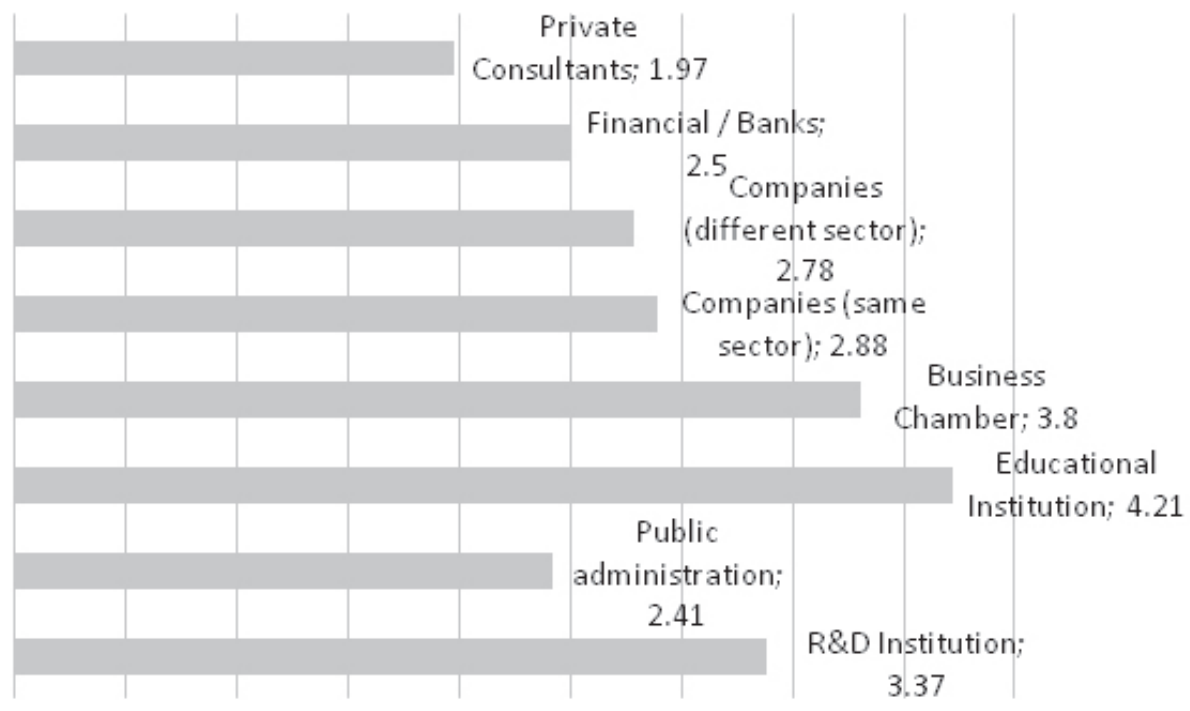

Collaboration with companies from the same sector was indicated as more important than a network with companies from a different sector. Indeed, cooperation with other companies can be even more important than cooperation with public administrations (Zeng et al., 2010).

Companies in clusters of firms and inter-firm networks can certainly realise competitive advantages (Enright et al., 2001). As a matter of fact, it became 
much easier for SMEs to build networks of their own, with partner companies from far away, by utilising the new communication technologies that were developed in the last decades, even though many firms still lack the crucial technology infrastructure (Michaelides et al., 2013). However, in the current knowledge society, a collaboration of companies only is not sufficient.

While most companies were primarily innovating from within, without using external resources, they are opening up and becoming part of the emerging "open innovations" environments (Chesbrough, 2003). The basic idea of open innovation is that, in a world of widely distributed knowledge, companies cannot afford to rely entirely on their own research, but need to find and connect to other parties and explore multiple channels. This holds also true for SMEs that are discovering the benefits from open innovations to meet customer demands, while they face the challenge of organisational and cultural issues as a consequence of dealing with increased external contacts (Van de Vrande et al., 2009). Open innovations ask for a corresponding business model, allowing the successful implementation (Van der Meer, 2007). Actually, it can be easier to adopt such a business model by a small company than a large company that is less flexible (Chesbrough, 2013).

SMEs have less R\&D resources and innovate in more different ways than major companies (Tödtling \& Kaufmann, 2001). Networking with intermediaries can be a very effective way for SMEs to facilitate open innovation for and among smaller companies (Lee et al., 2010). Such networking with chambers or academic institutions asks for a reliable, trustful partnership.

\subsection{Work-based learning to combine innovation and education}

Work-based learning, the combination of school training and practical training, is deeply rooted in the German education system (Dessinger, 2002). It has been often discussed whether this so-called dual system could be a model for modern vocational training (Blossfeld, 1992).

Young people avoid vocational training and prefer studies. However, most courses are largely theoretical and not sufficiently focused on the practical issues of SMEs, which cannot develop a sufficient number of entrepreneurs and skilled workers despite a large number of students. Dual courses of study, which combine vocational training or activity with studies, have to be established on a broad basis to close the skills mismatch described above. Well-designed workbased learning curricula have clear advantages and prove to be very effective (Lester \& Costley, 2010). The training on the job also enhances the personal 
skills of the students, who are engaged in customer meetings, having to cope with co-workers, etc. and thus already have the practical experience that graduates who only attend university lack.

Dual courses of study can be combined ideally with direct promotion of innovations. The participants of dual courses of study attend university courses and at the same time work in a company. This results in direct relationships between universities/colleges and SMEs, which are used for personal counselling and transfer processes.

The students are an untapped resource, a living bridge between the academic world and the business world. They can share the precise needs of their company with the professor and vice versa inform the company about possible new interesting research results. As part of semester or bachelor thesis, manageable research and development tasks can be conducted in direct cooperation between enterprises and universities. Evidence shows that the dual training method tends to be even better than the full-time college-based training method and consequently stronger trainees arise from the work-based learning programs (Nickolaus et al., 2009). Feedbacks from the companies involved in workbased learning confirm that these graduates have excellent job opportunities (Kiedrowski \& Schaumann, 2011).

Dual study courses are so far implemented mainly in Western countries such as Netherlands, Austria, and Germany. Close collaboration with universities and schools from EaP countries are needed to extend these to Eastern countries.

\section{Conclusion}

To stay competitive it is essential for SMEs to benefit from partnerships between business organisations and academic institutions. Most effective are transnational partnerships, involving the Eastern and Western countries that distribute according to their strengths. These partnerships, like the Baltic Sea Academy, should concentrate on the realisation on tangible innovative solutions in the short run and create educational curricula for future employees to address the issue of the urgently needed skilled workforce in the long run. An ideal education, connecting academic knowledge and the business world are curricula in a work-based learning environment.

The EU Eastern Partnership represents the Eastern dimension of the Neighbourhood Policy. It strengthens bilateral relations between the EU and 
its Eastern European partners. One of the objectives of this partnership is the economic integration by supporting the socio-economic reforms and promoting international cooperation. Considering the economic aspects of countries and regions in both EU and EaP countries, as mentioned already above, international cooperation is essential for the economic growth of companies. In the globalised world, however, the economic growth is strongly limited, if the companies are constrained or do not have the possibility to access the international markets. Especially small and medium-sized companies face this challenge due to limited human and financial resources. This is why cooperation at different levels (regional, national, and international) and between different stakeholders is of crucial importance. Cooperation only between SMEs is no longer satisfactory. Other cooperation forms have to be promoted and supported, for example, between SMEs and academic institutions in order to enhance the innovation potential and competitiveness of companies and thus to strengthen the international trade ties in the EU and the countries of EaP.

Max A. Hogeforster, Ph.D. specialises in law studies at the universities of Bonn, Salamanca and Berlin. His focus of study is commercial law and European law, and his postgraduate studies concentrate on mediation, e-commerce, and EU law. He has been teaching mediation since 2001. Since 2010, Max Hogeforster is chairman of the Baltic Sea Academy, an association of 17 universities and polytechnics from 9 countries. He is the editor and publisher of several articles and books regarding the development of European small and medium-sized enterprises, with a particular focus on innovation and education.

Elina Priedulena specialises in sociology, pedagogy and geography studies at the GeorgAugust University in Göttingen with the focus on comparative research in education and society, and effects of economic development in the Baltic States. She works as a tutor and supervisor at the Center of Methods in Social Sciences at the Georg-August University and since 2011 as project manager at the Hanse Parlament, an association of more than 50 chambers of crafts, industry and commerce in the Baltic Sea Region since 1994. Elina is coordinator of projects focusing on vocational education, SMEs, innovation, and energy issues in the Baltic Sea Region. 


\section{References}

Abreu, M.; Grinevich, V.; Hughes, A.; Kitson, M. \& Ternouth, P. (2008), Universities, Business and Knowledge Exchange, Council for Industry and Higher Education. Retrieved from http://www3.cardiffmet.ac.uk/English/ management/workbasedlearning/CCWL/Documents/Library-Documents/134\%20 Universities,\%20Business\%20and\%20Knowledge\%20Exchange.pdf [accessed 10 Jun 2014]

Altenburg, T. (2008), “Breakthrough? China's and India's Transition from Production to Innovation," World Development, vol. 36, no. 2, pp. 325-344.

http://dx.doi.org/10.1016/j.worlddev.2007.06.011

Baumol, W. J. (2002), The Free-Market Innovation Machine: Analyzing the Growth Miracle of Capitalism, Princeton: Princeton University Press.

Biermann, U.; Boll, C.; Reich, N. \& Stiller, S. (2013), 'Economic Perspectives, Qualification and Labour Market Integration of Women in the Baltic Sea Region,' Baltic Sea Academy Series, vol. 9, pp. 29-35.

Blossfeld, H. P. (1992), 'Is the German Dual System a Model for a Modern Vocational Training System? A Cross-national Comparison of How Different Systems of Vocational Training Deal with the Changing Occupational Structure,' International Journal of Comparative Sociology, vol. 33, nos. 3-4, pp. 168-181.

http://dx.doi.org/10.1177/002071529203300302

Cedefop (2014), Cedefop - European Centre for the Development of Vocational Training, Skill Mismatch: More than Meets the Eye, Briefing Note, March 2014. Retrieved from http://www.cedefop.europa.eu/EN/publications/22524.aspx [accessed 10 Jun 2014]

Chesbrough, H. W. (2003), Open Innovation: The New Imperative for Creating and Profiting from Technology, Boston, MA: Harvard Business School Press.

- (2013), Open Business Models: How to Thrive in the New Innovation Landscape, Boston, MA: Harvard Business School Press.

de Kok, J.; Vroonhof, P.; Verhoeven, W.; Timmermans, N.; Kwaak, T.; Snijders, J. \& Westhof, F. (2011), Do SMEs Create More and Better Jobs, Report prepared by EIM for the European Commission DG Enterprise and Industry, Brussels: European Commission.

Dessinger, T. (2000), “The German 'philosophy' of linking academic and work-based learning in higher education: the case of the "vocational academies'," Journal of Vocational Education and Training, vol. 52, no. 4, pp. 605-626. http://dx.doi. org/10.1080/13636820000200134

Eichhorst, W.; Hinte, H. \& Rinne, U. (2013), 'Youth unemployment in Europe: what to do about it?' Intereconomics, vol. 48, no. 4, pp. 230-235. 
Enright, M. J.; Fowcs-Williams, I. \& Nolan, A. (2001), 'Local partnership, clusters and SME globalisation. Enhancing SME competitiveness,' OECD Bologna Ministerial Conference / Organisation for Economic Co-operation and Development, pp. 115-150.

European Commission (2011), Report from the commission to the council and the European parliament, Minimizing regulatory burden for SMEs, Adapting EU regulation to the needs of micro-enterprises, COM (2011) 803 final, 23 November 2011. Retrieved from http://ec.europa.eu/governance/better_regulation/ documents/minimizing_burden_sme_EN.pdf [accessed 10 Jun 2014]

Eurostat (2012), Europe in Figures - Eurostat Yearbook 2012: Population, European Commission.

Gagliardi, D. et al. (2013), A Recovery on the Horizon, Annual report on European SMEs 2012/2013 for the European Commission. Retrieved from http://ec.europa. eu/enterprise/policies/sme/facts-figures-analysis/performance-review/files/ supporting-documents/2013/annual-report-smes-2013_en.pdf [accessed 10 Jun 2014]

Heinonen, J. (2010), 'Business in the Baltic Sea Region - future perspective,' Baltic Rim Economies Quarterly Review, vol. 3, p. 46.

Hogeforster, M. (2014), 'Future Challenges for Innovations in SMEs in the Baltic Sea Region,' Procedia - Social and Behavioral Sciences, vol. 110, pp. 241-250. http://dx.doi.org/10.1016/j.sbspro.2013.12.867

Holm, D. B.; Eriksson, K. \& Johanson, J. (1996), 'Business networks and cooperation in international business relationships,' Journal of International Business Studies, vol. 27, no. 5, pp. 1033-1053.

Lee, S.; Park, G.; Yoon, B. \& Park, J. (2010), 'Open innovation in SMEs-An intermediated network model,' Research Policy, vol. 39, no. 2, pp. 290-300. http://dx.doi.org/10.1016/j.respol.2009.12.009

Lester, S. \& Costley, C. (2010), 'Work based learning at higher education level: value, practice and critique,' Studies in Higher Education, vol. 35, no. 5, pp. 561-575. http://dx.doi.org/10.1080/03075070903216635

Liu, X.; Hodgkinson, I. R. \& Chuang, F. M. (2014), 'Foreign competition, domestic knowledge base and innovation activities: Evidence from Chinese high-tech industries,' Research Policy, vol. 43, no. 2, pp. 414-422. http://dx.doi.org/10.1016/j.respol.2013.11.005

Lukács, E. (2005), 'The economic role of SMEs in world economy, especially in Europe,' European Integration Studies, vol. 1, no. 4, pp. 3-12.

Michaelides, R.; Morton, S. C.; Michaelides, Z.; Lyons, A. C. \& Liu, W. (2013), 'Collaboration networks and collaboration tools: a match for SMEs?' International Journal of Production Research, vol. 51, no. 7, pp. 2034-2048. http://dx.doi.org/ 10.1080/00207543.2012.701778 
Nickolaus, R.; Gschwendtner, T. \& Geissel, B. (2009), 'Social inequality as an enduring phenomenon of general and vocational education - characteristics in the Federal Republic of Germany and international perspectives,' CEDEFOP European Journal of Vocational Training, vol. 46, no. 1. Retrieved from http://www.cedefop.europa.eu/EN/Files/EJVT47_en.pdf [accessed 10 Jun 2014]

Odenrick, P. (2012), SME relevant sectors in the BSR: Personnel organization, energy and construction, Baltic Sea Academy Series, vol. 5, pp. 9-52.

Siebert, H. (1997), Labor Market Rigidities and Unemployment in Europe, Kiel Working Papers, no. 787. Retrieved from http://www.econstor.eu/ bitstream/10419/934/1/224916742.pdf [accessed 10 Jun 2014]

Stiller, S. \& Faltermeier, J. (2011), Auswirkungen des demographischen Wandels auf die Arbeitsmärkte im Ostseeraum, Baltic Sea Academy Series: Education Policy Strategies Today and Tomorrow around the "Mare Balticum", vol. 3, pp. 50-68.

Street, C. T. \& Cameron, A. F. (2007), 'External relationships and the small business: A review of small business alliance and network research,' Journal of Small Business Management, vol. 45, no. 2, pp. 239-266.

Soriano, F. H. \& Mulatero, F. (2010), 'Knowledge policy in the EU: From the Lisbon strategy to Europe 2020,' Journal of the Knowledge Economy, vol. 1, no. 4, pp. 289-302. http://dx.doi.org/10.1007/s13132-010-0020-9

Teichler, U. (2013), 'Universities Between the Expectations to Generate Professionally Competences and Academic Freedom Experiences from Europe,' Procedia Social and Behavioral Sciences, vol. 77, pp. 421-428. http://dx.doi.org/10.1016/j. sbspro.2013.03.097

Tödtling, F. \& Kaufmann, A. (2001), 'The role of the region for innovation activities of SMEs,' European Urban and Regional Studies, vol. 8, no. 3, pp. 203-215. http://dx.doi.org/10.1177/096977640100800303

Ubarevičienė, R.; Van Ham, M. \& Burneika, D. (2014), Shrinking Regions in a Shrinking Country: The Geography of Population Decline in Lithuania 2001-2011, Institute for the Study of Labour (IZA) Discussion Paper, no. 8026. Retrieved from http://ftp.iza.org/dp8026.pdf [accessed 10 Jun 2014]

UN World Population Prospects (2010), World Population Prospects: The 2010 Revision, New York: United Nations, Department of Economic and Social Affairs, Population Division.

Van de Vrande, V.; De Jong, J. P.; Vanhaverbeke, W. \& de Rochemont, M. (2009), 'Open innovation in SMEs: Trends, motives and management challenges,' Technovation, vol. 29, no. 6, pp. 423-437. http://dx.doi.org/10.1016/j.technovation.2008.10.001

Van der Meer, H. (2007), 'Open innovation - the Dutch treat: challenges in thinking in business models,' Creativity and Innovation Management, vol. 16, no. 2, pp. 192-202. http://dx.doi.org/10.1111/j.1467-8691.2007.00433.x 
Von Kiedrowski, J. \& Schaumann, U. (2011), Duale Bachelor Studiengänge: Konzepte und Erfahrungen der Berufsakademie Hamburg, Baltic Sea Academy Series, vol. 3, pp. 338-348.

Wymenga, P.; Spanikova, V.; Derbyshire, J. \& Barker, A. (2011), Are EU SMEs recovering? Annual Report on EU SMEs 2010/2011 for the European Commission, Rotterdam \& Cambridge: Ecorys. Retrieved from http://ec.europa.eu/enterprise/ policies/sme/facts-figures-analysis/performance-review/files/supportingdocuments/2010-2011/annual-report_en.pdf [accessed 10 Jun 2014]

Zeng, S. X.; Xie, X. M. \& Tam, C. M. (2010), 'Relationship between cooperation networks and innovation performance of SMEs,' Technovation, vol. 30, no. 3, pp. 181-194. http://dx.doi.org/10.1016/j.technovation.2009.08.003 